\title{
Class, Community, and the Labor Movement in Wales and Canada, 1890-1930
}

\author{
Deian Hopkin \\ University College of Wales
}

On the face of it, Canada and Wales would appear to be unlikely companions in a comparative study; the discrepancies in scale, geography, location, ethnicity, and culture suggests that any comparison is likely to be superficial and contrived. Yet over recent years, there have been growing links between Wales and Canada, even though relatively few people have migrated in either direction. In some measure, this is due to the proselytizing work of the Canadian Studies in Wales Group (CSWG), an interdisciplinary body that was formed in 1983 and has been energetically organizing conferences and seminars and publishing pamphlets and reports. On the other side of the ocean, too, there are active labor history societies. The Committee on Canadian Labour History and its journal, Labour/Le Travail, will be well known to readers of $I L W C H$, as they are in Wales. The impressive output of books and articles, the energy with which the Canadians have sought to construct their historiography, and the extent of their international contacts, have long been admired in Wales. Llafur, the Society for the Study of Welsh Labour History, was formed in 1971 and its journal, Llafur (the Welsh word for labor), was first published in the following year. Unlike most labor history societies in Britain, Llafur has always maintained strong links with the trade-union movement. Its committee contains trade unionists as well as academics, while the program of day schools, workshops, and the highly successful residential Easter School have ensured a wide participation by the seven hundred members in the work of the society.

The suggestion for a joint conference arose when the editors of Llafur and Labour/Le Travail, Deian Hopkin and Greg Kealey, happened to meet in Germany in 1985 as members of Dirk Hoerder's project on working-class immigrant culture in the United States. The idea took root when Denis Balsom, the enterprising treasurer of the CSWG, offered to find pump-priming funds (always a major problem in Thatcher's United Kingdom).

The objectives of the symposium, held at Gregynog Hall in Newtown, MidWales, were twofold. Clearly, we sought to create a bridge between two organizations that pursued a similar task - the encouragement of an awareness of the historical dimensions of working-class consciousness. More specifically, the symposium sought to explore the factors common to two countries very

International Labor and Working-Class History

No. 33, Spring 1988, pp. 90-93

(C) 1988 by the Board of Trustees of the University of Illinois 
different in size and character but similar in historical location and, to some extent, experience. Both Wales and Canada have been shaped in part by their proximity to an imperialist economy; the concomitant issues of colonization; the impact of migration; the complexities produced by culture, ethnicity, and language; the role of religion; and the problems of political identity. In both Wales and Canada, for example, bilingualism is a political as well as a cultural issue, while the search for administrative devolution in Wales has echoes of the federal issue in Canada.

The themes and chronology of the symposium were, to some extent, chosen arbitrarily and in anticipation of debate rather than as an attempt to channel and limit discussion to some preordained program. The main purpose of the conference was to exchange ideas, and the organizers tried hard to avoid dictating precise themes. As a result, the invited participants were given a good deal of freedom in their choice of topic. The list of papers offered was nearideal and formed several coherent blocks-the industrial experience, communities and culture (including religion), regional history, migration, women, and industrial and social conflict. Indeed, in his splendid end-of-conference summary, David Montgomery described some of the papers as quite memorable, and it was generally agreed that on this occasion at least, ambitious titles did not collapse under feeble delivery.

The symposium was opened by Dai Smith of Cardiff University College with an examination of popular culture in Wales which, in an idealized mode as well as in functional terms, has become both a weapon and a battleground in the search for a redefinition of Wales after 1880. Smith's paper was followed by a wide-ranging analysis by John Williams of Aberyst wyth University College of the performance of the Welsh economy from 1890 to 1930, and its implications for politics and society.

In the first group of Canadian papers, Robert Babcock from the University of Maine, the president of the Committee on Canadian Labour History, compared two cities as paradigms for labor and industrial capitalist development in Canada and the United States, while Craig Heron of York University, Ontario discussed the second industrial revolution in Canada in the context of the urban history of Hamilton. Both papers showed the degree to which Canadian historians have been influenced by human geography and urban analysis, directions that have provided Canadians with far more detailed local histories than we in Wales have so far enjoyed.

On the following day, there was a full program of papers, nine altogether grouped in four themes. Gerry Friesen of the University of Manitoba explored the impact of R. B. Russell, the Scottish immigrant who played such an important part in organizing the struggles of the machinists of Winnipeg and the One Big Union in 1919-20. Christopher Turner of Aberystwyth, in a contrasting paper, analyzed the relationship between nonconformity and the labor movement and raised a number of central questions about the quiescence of the 
Welsh working class. After the break, Merfyn Jones of Liverpool University analyzed patterns of conflict and capital in North Wales in the late nineteenth century, and examined the definition, locus, and aspirations of political activity in this important but complex industrial area. Hywel Francis, the tutorlibrarian of the South Wales Miners Library at Swansea, by contrast, examined relations between Welsh miners and Canadian labor in Canada itself and produced some unexpected points of detail about Canadian history.

The afternoon session dealt with specific groups of immigrants. Bruno Ramirez of the University of Montreal provided a complex analysis of the impact of immigration on regional labor markets, especially in Quebec, while Paul O'Leary of the Political Archive at the National Library of Wales discussed his own pioneering work on the Irish in Wales, especially in the context of labor politics. In the late afternoon and in a special session after dinner, three Canadian papers concentrated on regionalism in Canada. Bryan Palmer of Queen's University, Ontario raised a number of important general issues about the evolution of Canadian working-class movements in Central Canada, while Ian McKay of St. Mary's University, Nova Scotia traced the rise and fall of the industrial working-class movement in the Maritime Provinces, notably in the mining communities of Nova Scotia, Prince Edward Island, and New Brunswick. Allen Seager of Simon Fraser University, British Columbia concluded the session with a paper on miners' struggles in the Nanaimo community in British Columbia that was richly documented with census returns and official papers.

On the last day of the conference, there were three sessions. The morning was opened by a session on women's history. Dot Jones, of the Economics Department at Aberystwyth, compared the occupational structure of women in contrasting rural and urban communities in Wales, with special emphasis on their life experience and expectations. Lina Kealey of St. John's University, Newfoundland examined the particular role of women in the 1919 Canadian labor revolt, while Varpu Lindstrom-Best of York University, Ontario gave an illustrated history of the immigrant women of Timmins, Ontario in the interwar years.

After the break, there were two papers on industrial history. Greg Kealey examined the dimensions of class conflict as reflected in industrial relations and disputes in Canada between 1890 and 1926, while I undertook a similar exercise for Wales in the same period, with particular emphasis on the disjunction between the experience of miners and that of other occupational groups. The conference concluded after lunch with a comprehensive overview by David Montgomery of Yale University of the themes of the conference and a resumé of the issues and debates raised by the participants.

As always, a report such as this cannot convey the full value of such a conference as demonstrated in the discussions after the papers and at the end of the conference, and in the informal exchanges that took place after each day's 
work. But the abiding impression of the conference was the enormous friendship that was struck between two groups of historians. Instinctively and effortlessly, the Canadians and the Welsh became one harmonious group, together with the Scots, Irish, English, Americans, and Australians who were also there. The conference demonstrated that through meetings such as this, real long-term cooperation can be advanced. The quality of the papers and the discussions ensured the undoubted success of the whole occasion. In the long term, it has laid the foundation for an enduring relationship between the Welsh and Canadian societies. We plan the publication of the conference papers in a special volume to be published jointly by the two societies. 